\title{
Economic Nationalism and Maritime Policy in Norway
}

\author{
TORE FOUGNER
}

\begin{abstract}
While celebrating recent efforts to redefine 'economic nationalism' by placing nationalism and national identity - rather than the state or illiberal economic policies - at its core, this article takes issue with the tendency to provide an unnecessarily narrow specification of a new research agenda on economic nationalism. More specifically, it argues that the agenda should concern not merely how national identities and nationalism influence economic policies and processes, but also how the latter can influence the former. An argument is also made for this twoway relationship to be conceived in constitutive terms, and a study of the efforts to develop a maritime policy in Norway in the mid-1990s is presented to show the usefulness of this reformulated research agenda on economic nationalism.
\end{abstract}

Keywords: Economic nationalism; maritime policy; national identity; Norway; shipping

\section{Introduction}

While 'economic nationalism' has conventionally been used with reference to either a wide range of non-liberal economic policies or an economic version of the statist theory of realism within IR/IPE scholarship, several scholars have in recent years challenged these applications of the term, and called for national identities and nationalism to be placed at the core of the term's definition. More specifically, Eric Helleiner has argued in favour of a new research agenda being refocused on what he conceives to be the core problematic identified by Friedrich List: 'in what ways do national identities and nationalism influence economic policy and processes?' (2002: 326).

In this article, I make a three-fold contribution related to this new research agenda on economic nationalism. Firstly, I argue that the agenda in question should concern not merely how national identities and nationalism influence economic policies and processes, but also how economic policies and processes can influence national identities and nationalism. Secondly, I argue in favour of the two-way relationship in question being conceived in constitutive rather than causal terms. Thirdly, I present an analysis of economic nationalism in connection with efforts to develop a

Cooperation and Conflict: Journal of the Nordic International Studies Association Vol. 41(2): 177-201. Copyright (C2006 NISA www.ps.au.dk/NISA

Sage Publications www.sagepublications.com 0010-8367. DOI: $10.1177 / 0010836706063661$ 
maritime policy in Norway in the mid-1990s. To discuss these policy efforts in relation to economic nationalism only makes sense in the context of the term's redefinition, and I will use the case to bring out the co-constitutive relationship between Norway and Norwegians, on the one hand, and shipping and things maritime, on the other.

In the first section, I engage with Helleiner's call for a new research agenda on economic nationalism, and seek to expand it by both including a concern with how economic policies and processes can be conceived as productive in relation to both nation and national identity, and developing a basis for constitutive analysis of economic nationalism. Thereafter, a brief outline of the efforts to develop a maritime policy in Norway in the mid1990s will be given. In sections three and four, I proceed with an analysis of this policy as a site for nation (re)production and national identity (re)construction, respectively. In the fifth section, the focus shifts to the ways in which nationalism influenced the efforts to develop a maritime policy. As a final and critical dimension of the analysis, section six brings out the inclusions and exclusions connected with the nationalism integral to the maritime policy development.

\section{The New Research Agenda on Economic Nationalism}

According to Helleiner, two important arguments have emerged from recent attempts to sharpen the analytical concept of economic nationalism. ${ }^{1}$ Firstly, the main fault of traditional definitions of the concept in post-1970 IR/IPE literature is that they have rendered the nationalist content of the ideology absent by equating economic nationalism with statism or statecentric realism. Secondly, and with the nationalist content brought back in, economic nationalism can be associated with a wide range of policy projects — including liberal ones. To Helleiner, this openness as it concerns policy content follows logically from the first argument: 'Since national identities are so variable and changeable across time and space, we should expect the same of the policies that economic nationalists endorse' (2002: 310-1).

Through a study of the history of nineteenth-century economic nationalism, Helleiner seeks to give credibility to these ways of seeing economic nationalism. Firstly, he emphasizes that List defined economic nationalism not in terms of particular economic policy prescriptions, but rather with reference to the nationalist content of his ideas. In other words, his economic nationalism was primarily defined in terms of a 'nationalist ontology' and 'a nationalist objective of serving the interests of the nation as a collective community' (ibid.: 312). Secondly, Helleiner brings out how other economic nationalists advanced policies different from List's infant industry protectionism - cases in point being Thomas Attwood's nationalist critique of the gold standard, Johan Fichte's and Adam Muller's calls for economic autarchy, and a seemingly contradictory strand of 'liberal economic nationalism'. While clearly different with respect to policy content and prescriptions, Helleiner claims that they all shared 'the ideological core of economic nationalism identified by List: the commitment to examine how 
economic policy could be used to help a given nation obtain "prosperity, civilisation and power", (ibid.: 322).

Against this background, Helleiner suggests that the new research agenda on economic nationalism should focus on List's core problematic of how national identity and nationalism influence economic policy and processes. 'The goal', he states, should be 'to explore the diverse and complex ways that national identities and nationalism shape economic life' (ibid.: $327) .^{2}$ While finding Helleiner's analysis of the history of nineteenthcentury economic nationalism both convincing and stimulating, I feel that his specification of a new research agenda is too narrow and constraining in two ways: Firstly, he seems to be closing the door on an equally important aspect of economic nationalism - namely, the ways in which economic policies and processes can influence nationalism and national identity. Secondly, the research agenda is formulated in such a way as to limit research to a quest for causality as it concerns the relationship between things national and things economic. ${ }^{3}$

With regard to the former issue, the door in question has already been opened by one of the scholars that Helleiner draws on. According to George Crane (1998), one can distinguish between two broad conceptions of the relation of economy to nation. Firstly, economy can be considered external to nation or the socio-cultural imaginings that define it. This is undoubtedly the most common conception of the relation of economy to nation, and it informs a Listian concern with how things economic are or can be used instrumentally to serve a predefined nation. Secondly, economy can be considered internal to nation or the socio-cultural imaginings that define it. This less common conception of the relation of economy to nation informs Crane's concern with how 'economic life might (...) be imagined and constitute an important aspect of national identity' - this, in the sense that 'images of economic life can be, and are, used to inspire a sense of communion' (1999: 216). In this connection, he specifies three ways in which national narratives can be rendered in economic terms: economic-historical experiences of suffering can be made into powerful signs of collective identity; economic accomplishments can serve as emblems of shared glory; and assertions can be made of an organic societal unity rooted in a common economic life.

The two different conceptions of the relation of economy to nation are to some extent based on different conceptions of 'nation' and 'national identity'. As acknowledged by Helleiner, Crane is 'much more inclined than List was to emphasize the constructed and contested nature of national identities' (2002: 312). While List's nationalist ontology constitutes nation and national identity as parts of a seemingly given order of things, Crane argues that '[a]ny particular conception of nation is fragile, in need of constant reassertion and reinvention to make the lived present consonant with some remembered past' (1998: 73). However, and although Crane stresses 'the inherent instability of national identity' (ibid.), it is unclear if he conceives of nation as given prior to the socio-cultural imaginings that define it, or if national identity and nation are both conceived as products of such imaginings. 
Whatever the case, I will adopt Craig Calhoun's conception of nations as 'discursively constituted subjects, even if the rhetoric of their constitution is one that claims primordiality or creation in the distant, seemingly prediscursive, past' (1995: 251; 1997). In this understanding, a group of people makes up a nation only to the extent that it is ascribed meaning as such in and through nationalism understood as a theory or system of representation that portrays humanity as being divided into nations. Furthermore, there is no nation outside of inter-nationalism, since '[y]ou cannot have a sense of belonging to the same nation as your neighbors unless you are aware of it as a nation among others and of an imagined totality of nations forming, eventually, a kind of world system' (Rée, 1998: 83). In other words, a group of people is constituted as a nation not in isolation from the rest of humanity, but rather in relation - if not opposition - to other nations.

The last point can be made also with regard to the notion of 'national identity'. In contrast to a common-sensical and 'essentialist' conception of identity as that which 'a person or a group (...) really is, uniquely, in and of itself, in its inner being and without reference to externals' (Handler, 1994: 28 ), identity can be claimed always already to be a matter of constructed identity/difference. In accordance with William Connolly's (1991) claim that there can be neither identity without difference nor difference without identity, national identity must be considered ontologically co-constructed with inter-nationalized difference. As such, it must furthermore be seen as an unstable production that is 'never complete, always in process, and always constituted within, not outside, representation' (Hall, 1990: 222).

With nation understood as a representational product with no ontological status outside of nationalism, a group of people is constituted as a nation not once and for all through a founding act of representation, but rather in and through continuous processes of (re)production. In this connection, it is necessary to move beyond the tendency to equate nationalism with 'hot' struggles to produce new nations, and consider also the 'banal nationalism' that Michael Billig (1995) has claimed follows from the enhabitation of the theory of nationalism: '[A]s the world of nations is set in place as the world, so the theory also becomes enhabited in common sense. It ceases to seem theoretical, but is embedded in habits of thought and life' (ibid.: 63). In other words, banal nationalism can be conceived as 'a whole complex of beliefs, assumptions, habits, representations and practices' (ibid.: 6) that work in mundane ways to (re)produce seemingly well-established nations on a daily basis.

As to the second constraint of Helleiner's research agenda on economic nationalism, it follows from the above that the favoured mode of analysis in the present study is constitutive - this, in the sense that it aims to bring out how things economic can be or become constitutive of nation and national identity. In this connection, it should be emphasized that the constitutivity in question is considered a feature not of things economic themselves, but rather of the representational practices in and through which they are ascribed meaning. Such a constitutive mode of analysis differs from the causal one that informs Helleiner's concern with how nationalism and national identity influence economic policies and processes. ${ }^{4}$ In this case, a 
particular nationalist sentiment or national identity is seemingly given independently of and prior to economic policies and processes, and the aim of analysis is to explain the latter with reference to the former.

In order to take on board also a version of the from-nation-to-economy problematic identified by List and Helleiner, the concern with how things national can influence economic policies and processes must be reconceived as a concern with how the former can be or become constitutive of the latter - again, with constitutivity being a feature of the representational practices in and through which things national are ascribed meaning. Overall, then, the re-formulated research agenda on economic nationalism proposed here is concerned with the co-constitutive relationship between nationalism, nation and national identity, on the one hand, and economic policies and processes, on the other. More generally, and given that it is nationalism understood as a system of representation that enables economy to become a constitutive aspect of nation and vice versa, the agenda concerns how nation and economy are co-constituted within the nationalist system of representation.

With regard to the empirical study that follows, this translates into an attempt to bring out how Norway and shipping were co-constituted within the nationalist system of representation in connection with the efforts to develop a maritime policy in Norway in the mid-1990s. Before attending to this, however, a brief outline of these policy efforts is warranted.

\section{Towards a Maritime Policy in Norway}

On 19 May 1994, the following resolution was passed by the parliament in Norway:

The Storting requests the government to submit a white paper on Norwegian shipping policy and maritime activity. In it, maritime business activity in Norway should be discussed in a broader industrial and international perspective in order for the prospects of increased value creation and employment to be assessed. (S.tid., 1993-94: 3932)

A sense of both continuity and discontinuity permeated this resolution. On the one hand, it referred to 'shipping policy' as an established policy field for state authorities, at the same time as the requested white paper was generally referred to as 'a new shipping white paper' during the parliamentary debate - that is, a white paper that would follow in the line of the many such submitted in the wake of the shipping crisis in the mid1970s. On the other hand, it is clear from both the wording of the resolution and the debate preceding it that shipping was no longer to be considered in isolation from other lines of business in a policy context. In short, what the parliament requested was 'an appraisal of a future maritime policy' (Ludvigsen in S.tid., 1993-94: 3930), and what came out of the process in 1996 was the first 'maritime white paper' ever submitted by a government in Norway. 
Although such a comprehensive shipping policy had been proposed by the Norwegian Shipowners' Association (NSA) in the late-1980s, the parliament's resolution was more directly enabled by research conducted on the basis of Michael Porter's (1990) cluster theory of the competitive advantage of nations. Of particular significance in this connection was the 'Norwegian Porter project' (Reve et al., 1992), which had sought to replicate Porter's national studies in the context of Norway. The important point to note here is that the project's mapping of 'the international competitiveness of the Norwegian business community' (ibid.: 15) led to the identification of shipping as the core and driving force of 'the most complete, the most international and the most knowledge-based' industrial cluster in Norway - namely the so-called maritime-industrial cluster.

Following the parliamentary request, Trade and Shipping Minister Grete Knudsen appointed a Maritime Idea and Resource Group (MIRG) made up primarily of representatives of various shipping-related lines of business to assist the Ministry of Foreign Affairs in preparing the white paper. The group met 10 times between January and September 1995, and its final report (MIRG, 1995) drew extensively on Porter-inspired research on the maritime businesses, proposed several policy measures aimed at strengthening shipping-related business activities in Norway, and laid the foundation for the Labour government's white paper Where ships can float .... The maritime businesses (St.meld., 1995-96). Both the latter and a parallel bill on changes in shipping taxation (Ot.prp., 1995-96) were submitted to the parliament on 15 March 1996.

With the exception of two small socialist parties, the white paper was very well received in the parliament. The Trade and Shipping Minister was honoured for the way in which she had prepared the white paper, and there was broad cross-party agreement on both the feasibility of Norway making an extra effort in the maritime lines of business and most of the measures proposed by the government towards that end. The only contentious issue was that of shipping taxation, where the conservative opposition argued that the government's proposal to increase the tax-related depreciation rate for ships from $20 \%$ to $23 \%$ had not gone far enough in providing foreign-going shipping with 'competitive tax conditions'. Following a heated debate both inside and outside the parliament, the opposition's counter-proposal for income tax exemption prevailed.

\section{Maritime Policy and the (Re)production of Norway as a Nation}

Although Norway has been represented as a nation since the emergence and spread of nationalism in the late-eighteenth and early-nineteenth century (Sørensen, 1998), it follows from the earlier discussion that Norway's status as a nation depends on it being ascribed meaning as such in and through the nationalist system of representation on a continuous basis. In what follows, I conceive of the maritime policy as a site for such nation (re)production, and bring out the specific ways in which Norway was 
articulated within the nationalist system of representation and, consequently, (re)produced as a nation. In this connection, Norway can be claimed to have been thus (re)produced in at least five different ways in connection with efforts to develop a maritime policy.

Firstly, it was (re)produced as a nation in and through its explicit conceptualization as such. In this connection, it can initially be pointed out that frequent use of the words 'nation', 'national' and 'international' in connection with the efforts to develop a maritime policy worked to conjure up a world that first and foremost consisted of nations and their relations - that is, an inter-national world. While this alone worked to establish a link between the proper name 'Norway' and the term 'nation' - and hence to constitute Norway as one among several nations - the link in question was also made in more explicit terms. At times, and as if to remove all doubt as to what Norway was, the noun phrase 'Norway as nation' was used. A case in point is the wording of MIRG's mandate: 'The group shall provide opinions as to what position Norway as maritime nation, in strong international competition, should and can have in the future' (MIRG, 1995: 9; emphasis added).

Secondly, Norway was (re)produced as a nation in and through the use of what Billig (1995) has called 'the deixis of homeland'; that is, the banal flagging of a national homeland through the use of little words of linguistic deixis, the meanings of which are fully determined by the context of their utterance. Two cases in point are the pronoun 'we' and the possessive noun 'our', both of which were frequently employed in the representational practices connected with the efforts to develop a maritime policy. When used in the MIRG report, it was implicitly clear that they referred to neither the authors of the report nor the maritime lines of business that most of them represented, but rather to Norway. When used by members of parliament, it was equally implicit that the words referred to neither the political party they represented nor all the members of parliament, but rather to Norway. Again, it can be mentioned that the link between the pronoun 'we' and the term 'nation' was also made more explicitly, as in the case of the noun phrase 'we as nation' (MIRG, 1995: 7, 9; St.meld., 1995-96: 6, 12).

Thirdly, Norway was (re)produced as a nation in and through an internationalization of economic competition. The notion 'inter-nationalization of competition' is used here with reference not to a shift in economic competition from a national to an international arena, but rather to how competition is framed in inter-nationalist terms. The immediate implication of such a framing is to constitute nations as the basic competitive entities. With reference to the above quote from the mandate given to MIRG, for instance, the inserted clause 'in strong international competition' works to (re)produce Norway as a nation in and through its constitution as one among several nations engaged in economic competition with each other. The same follows from the prominence of 'international competitiveness' concerns in connection with both the efforts to develop a maritime policy, and the theory and research informing them.

Fourthly, Norway was (re)produced as a nation in and through a nationalization of a part of world maritime business activity - this in the sense that such activity was constituted as 'Norwegian' or 'our' within the 
nationalist system of representation. While to a large extent a specific case of the above-mentioned inter-nationalization of economic competition, what justifies singling it out is, firstly, the overall maritime context in which Norway was (re)produced as a nation and, secondly, the more detailed way in which the inter-nationalization in question was enacted - including, not least, in and through statistical representations of world maritime activity. In spite of how even statistical overviews made use of qualitative terms such as 'leading', quantifications of 'Norway's maritime position' nevertheless worked to give a sense of substance to the representation of a part of world maritime activity as 'Norwegian'.

Fifthly, Norway was (re)produced as a nation in and through the ascription of a set of non-economic meanings to shipping and things maritime. In this connection, 'Norwegian shipping' was repeatedly claimed to be 'a significant part of Norwegian culture' (Brunæs in ibid.: 4231), and to have 'a cultural-historic status in coastal areas throughout the country' (Sponheim in O.tid., 1995-96: 574). Although frequent references to things coastal can seem to contradict the idea of maritime culture being shared by everybody in Norway, it is in perfect harmony with the white paper's geographical image of Norway: 'Geographically, Norway can be compared with a narrow island with short distance to the coast throughout the country' (St.meld., 1995-96: 50). That a maritime way of life concerned all Norwegians was made clear also in the opening paragraph of the white paper's preface: 'In Norway, people have always lived by the sea, of the sea and on the sea' (ibid.: 3). Against this background, the focus on things maritime as culture worked to constitute Norwegians as a people with a shared culture or way of life.

That the shared culture or way of life in question was not limited to the present was communicated through frequent references to 'traditions' in connection with the efforts to develop a maritime policy — whether in terms of Norway having 'long', 'honourable', 'proud' or 'rich' traditions in shipping, or in terms of 'our traditions' as a 'seafaring people' or 'shipping nation'. Continuity with the past was emphasized also by Minister Knudsen, who stated that 'Norway has a long, eventful and great past at sea' (S.tid., 1995-96: 4227). While the MIRG report included a short history of Norway as 'a maritime great power for one hundred years' (MIRG, 1995: 5), Reve et al. invoked the Viking age in the opening paragraph of their chapter on shipping: 'Norway is one of the world's largest shipping nations. Perhaps it was the Vikings who gave us such a good start in shipping, but in that case, there must still be quite a few Vikings in this country' (1992: 184).

Beyond constituting Norwegians as a people with a shared history, 'traditions' also invokes continuity with the past in genealogical terms. In this connection, the Norwegian Porter project leaves little doubt that the Vikings were Norwegians, and contemporary Norwegians are Vikings. Though separated by almost 1000 years, it is seemingly the same people cruising the waves. This genealogical dimension is also implicit in the use of the term 'generations' in connection with the efforts to develop a maritime policy. In the white paper, for instance, it was stated that '[w]e have through the generations had the ability to adjust ourselves and exploit new markets 
and new technology, and to set new boundary markers for international shipping' (St.meld., 1995-96: 3). Irrespective of how far back the familial notion of generations is stretched, the successive stages in natural descent that it invokes worked to inscribe a common ancestry onto people in Norway.

Overall, it follows from the above that the basis on which Norway was (re)produced as a nation - and, consequently, the type of nation it was constituted as - varied a great deal. Firstly, and with regard to its (re)production as a nation in and through an inter-nationalization of economic competition, the criterion determining nationality was domicile, and Norway was constituted as a nation in economic-territorial terms. Secondly, and with regard to its (re)production as a nation in and through a nationalization of a part of world maritime activity, the criterion determining nationality was citizenship, and Norway was constituted as a nation in juridico-political terms. Lastly, and with regard to its (re)production as a nation in and through the ascription of non-economic meanings to maritime business activity, Norway was constituted as a nation in ethno-cultural terms, and the criterion determining nationality would be the sharing of a common culture, traditions, history and ancestry.

\section{(Re)ascription of a Sea-Related Identity to Norway}

In connection with the efforts to develop a maritime policy, Norway was (re)produced not merely as a nation, but as a maritime nation. In explicit terms, this is clear from the very frequent use of both the notion 'maritime nation' and the noun phrase 'Norway as maritime nation'. Although the representation of Norway as a specifically maritime nation was novel in connection with the efforts to develop a maritime policy, it operated in parallel to and drew force from representations of Norway as a 'seafaring nation' or 'shipping nation'. While used interchangeably in connection with efforts to develop a maritime policy, representations of Norway as either a seafaring or a shipping nation have conventionally been used with reference to, first, all activity and, second, commercial transportation activity, at sea, respectively. In contrast, the representation of Norway as a maritime nation was used with reference to commercial activity at sea and on land.

Irrespective of this, and based on a reconceptualization of the issue in hand as one concerning national identity (re)construction rather than nation (re)production, it can be argued that Norway was ascribed a maritime identity in two different ways in connection with the efforts to develop a maritime policy. Firstly, it was ascribed such an identity in and through the constitution of maritime business activity as an inter-national 'marker of difference'. This follows from how the inter-nationalization of maritime business activity worked to constitute Norway not only as a nation, but as a nation engaged in maritime business activity. In spite of how a sufficiently detailed inter-nationalist representation of such activity would constitute most nations as 'maritime nations', inter-national comparisons 
enabled Norway to be represented not as any kind of nation engaged in maritime business activity, but as a 'maritime great power'.

Secondly, Norway was ascribed a maritime identity in and through a maritimization of Norway and Norwegians. This follows from how the ascription of non-economic meanings to things maritime worked not only to constitute Norwegians as a people with shared culture, traditions, history and ancestry, but also to infuse a maritime content into that which Norwegians seemingly shared. In other words, Norwegians were constituted as a people sharing not any culture, but a maritime culture; not any traditions, but maritime traditions; not any history, but a maritime history; and not any ancestry, but a maritime-related ancestry. Moreover, the relationship to the sea was represented as a key characteristic of what Norway and Norwegians really are and seemingly always have been. As for instance stated in the opening paragraph of the white paper's preface: 'Without sea and ocean, Norway and Norwegians would have been something else than what we are' (St.meld., 1995-96: 3; emphasis added).

The two ways in which Norway was ascribed a maritime identity correspond to a constructivist and an essentialist identity conception, respectively. In this connection, the maritime identity ascribed to Norway in and through the constitution of maritime business activity as an inter-nationalist marker of difference can be considered unstable, always in process, and dependent on continuous practices of inter-nationalist representations of world maritime business activity for its (re)construction. In contrast, the maritime identity ascribed to Norway in and through the maritimization of Norway and Norwegians seems solidly anchored in that which Norway and Norwegians really 'are' in and of themselves, and without reference to externals. While the former would be vulnerable to the shipowners' threat to move their activities out of Norway unless granted tax concessions, the latter would seemingly remain even if the entry 'Norway' should disappear from inter-nationalist representations of world maritime activity.

In spite of this, the maritime identity is primarily a product of the constitution of maritime business activity as an inter-nationalist marker of difference. Moreover, the essentialist identity construction is not only enabled by this unstable production of Norway as a contemporary maritime nation, but should itself be considered in representational terms: Rather than being anchored in an extra-representational reality, it is a product of an essentializing story about what Norway and Norwegians are. While 'contemporary greatness at sea' is written into this story as the most recent chapter, the plausibility of the whole story depends on the production of Norway as a contemporary maritime nation in and through inter-nationalist representations of world maritime activity. In other words, if Norway could not be thus (re)produced as a maritime nation, it would not make much sense to ascribe a maritime essence to Norway and Norwegians.

If the essentialist construction of a Norwegian maritime identity should seem to have a more solid anchorage, then it follows from how it connects with a sea-related construction of what Norway and Norwegians 'are' that preceded the efforts to develop a maritime policy. Having said this, however, it must be stressed that Norway has not always been conceived of as 
a nation with such a sea-related identity. In accordance with the general tendency to search for authenticity in areas considered unpolluted by civilization, most nationalist representations of Norway since the lateeighteenth century have portrayed it as rooted among peasants in the mountain wilds of southern Norway. When a sea-related dimension was painted into the nationalist picture during the second half of the nineteenth century, it followed not so much from a nationalist quest for things Norwegian, as from liberalist practices of economic government. The key figure in this connection was political economist and parliamentarian Anton Martin Schweigaard, who not only fought to '[m]ake Norwegian shipping as free as possible' (quoted in Bergh and Hanisch, 1984: 45), but also argued as follows during a parliamentary debate on a commercial treaty with France:

Those gentlemen, who live inland in the mountains, claim: 'We represent the Norwegians'. But those, who live by the coast, do so to an even greater extent. If we return to our old history, then we see evidence of this. What was it that we did, which deserved to be talked about? Was it our fights here at home? No, it was that we discovered America, and that we placed significant monuments by all oceans. (S.tid., 1865: 31)

As shipping was 'made free' and prospered at the expense of other lines of business, the politico-economic representation of Norway as a 'seafaring nation' was complemented with artistic representations. The most central person in this connection was the nationalist and 'poet chief' Bjørnstjerne Bjørnson. As noted by Jacob S. Worm-Müller:

No Norwegian poet has managed to portray the sea, the sea industry and the seaman's spirit as Bjørnstjerne Bjørnson. (...) He has as nobody else elevated the men and activities of the sea so high that everybody can see them, created a national sense of community, and sung us together as a people. $(1939: 23,27)$

In this connection, it can be mentioned that it was from a song that he wrote for a boat gathering in 1868 that not only the oft-repeated stanza 'our honour and our power, have white sails us brought' is taken, but also the title of the maritime white paper: 'The Norwegian seaman is a thoroughly toughskinned race, where ships float, there he is the first man.'5

Additional force was given to the representation of Norway as a 'seafaring nation' in connection with a change in the popular conception of the Viking age at the time. According to Haavardsholm (1999), the excavation of the Gokstad ship in 1880 contributed significantly not only to stimulate an interest in the Viking age, but also to draw attention to its 'shipping'. Although another Viking ship had been excavated in 1867, the Gokstad ship was better preserved, and its size came to serve as proof that the Vikings had had the means to cross large oceans, and that the Norwegians were the true descendants of the Vikings. Approximately a decade later, a copy of the Gokstad ship was named 'Viking' and sailed across the Atlantic Ocean to partake in the Columbian World Exhibition in Chicago in 1893. 
As outlined by historian Gustav Storm in 1892, the aim of the trip was to give people 'an impression and understanding of how our forefathers, the old Vikings, sailed on their many and long journeys', and 'for our flag on the Viking ship to give evidence about the Norwegian seaman's fearlessness in the past and the present' (quoted in Haavardsholm, 1999: 310).

With regard to the growing interest in the Viking age, Haavardsholm has also emphasized the importance of Storm's new translation of Snorre Sturlason's (1899) Kings' Sagas, and Alexander Bugge's (1904-06) The Vikings: Pictures from Our Forefathers' Lives. In the present context, the latter is of particular importance, as it contributed significantly to creating a conception of both the Viking age as an udfardstid (era of outward movement) and the Viking as a seafarer. According to Bugge, 'love of the sea' was an essential characteristic of the Vikings, and 'the sea is the Viking's true home'. At the time, this was supposedly reflected not only in shipping, but also in maritime expeditions: 'In the last years of the 19th century, the Norwegian Viking spirit has been reflected in the Arctic expeditions' (Kiær, 1900: 305). As with ship excavations, such expeditions were 'given one common denominator, namely the blood tie between the Vikings and the Norwegians of the nineteenth century' (Nereid, 1996: 34).

In the period leading up to the dissolution of the union with Sweden in 1905, the role of shipping as an inter-nationalist identity/difference-marker was further strengthened in connection with two intra-union conflicts namely 'the flag dispute' and 'the consular dispute'. While the former concerned the extent to which 'Norwegian' ships should be allowed to sail the flag of Norway, the latter concerned the quest for an independent foreign policy in the form of a separate consular service to serve 'Norwegian' shipping interests. The consular dispute is conventionally seen to have contributed significantly to the dissolution of the union, placing shipping at the centre of the political processes in and through which Norway was constituted as an independent nation-state — with shipowner Christian Michelsen as the first prime minister.

\section{Nationalist Effects on the Efforts to Develop a Maritime Policy}

Turning to the problematic derived from List and Helleiner, this section focuses on the effects of nationalism on the efforts to develop a maritime policy. More specifically, the concern is with the ways in which nationalism influenced how it was possible for policy-makers to think and act in relation to shipping and shipping-related lines of business. An immediate consequence of this fairly narrow focus is that I will have nothing to say about the possible effects of the nationalism in question on people in Norway more generally. In spite of this, a few words can feasibly be said about how the policy-makers more overtly sought to inspire a sense of national community and mission in connection with the efforts to develop a maritime policy.

Attempts to rally the nation behind a maritime policy and the maritime lines of business accorded with a less publicized guideline provided by the 
Norwegian Porter project. When discussing the sources of national competitiveness, Reve et al. stressed that a 'national mentality and co-operative will can in certain instances be determining for what we can manage to achieve' (1992:30). By drawing a parallel to 'our own national sport' of skiing through a case study on 'Norwegian Olympic gold in Albertville', the message was clear: 'we' compete with other nations in sports and business, and the infusion of a national mentality and nationalist hero-worshipping into inter-national economic competition can bring 'our' firms and 'us' the same success as it has brought 'our' athletes in inter-national sports competition. With shipping constituted as 'our own national industry', a policy directed towards it and related lines of business should make international competition in these industries a question of 'national prestige', and engender 'unambiguous attitudinal support' on the part of 'a united Norwegian people'.

In connection with the efforts to develop a maritime policy, attempts to rally people behind the maritime lines of business were most evident in the constant reiteration of Norway being a 'maritime great power'. The representation of contemporary 'greatness at sea' was supplemented with the construction of two periods of shared national glory in the past: The socalled golden age of sail shipping in the latter half of the nineteenth century, and the more distant shipping of the Viking age. In accordance with Crane's discussion on how economic accomplishments can serve as emblems of shared glory, 'greatness at sea' was constituted as a deed performed by Norwegians together, and the projection of a strong national will into a maritime policy held out the promise of additional great deeds and shared glory in the future. 'Our honour and our power have white sails us brought', it was re-stated, and 'we wish as much today that the same pious wish can follow our ships on all oceans, with the Norwegian flag visible to everybody' (Nistad in S.tid., 1995-96: 4222).

Such overt nationalism aside, it is time to turn to how the nationalism integral to the efforts to develop a maritime policy influenced how it was possible to think and act in relation to shipping. In this connection, it can be argued firstly that it had the effect of nationalizing shipping and shippingrelated lines of business - this in the sense that their wellbeing was constituted as being of great importance not merely to those directly involved in them, but also to the nation, Norway and all Norwegians. While integral to the policy efforts in question, such nationalization can also be considered a condition of possibility for the authorities claiming responsibility for 'national affairs' to get engaged in the policy efforts in the first place. Having said this, however, it should be mentioned that such engagement with shipping had long since been institutionalized in Norway, and that it thus might be more appropriate to talk about the authorities having been re-engaged in and through a (re)nationalization of shipping and related lines of business in connection with the maritime policy efforts.

This (re)engagement was prompted by both the Porter research conducted in Norway and warnings about an imminent crisis in shipping due to the tax conditions in Norway. While the former worked to authorize the authorities to engage in a pro-active cluster policy aimed at the 
maritime-industrial cluster, the latter worked to oblige the authorities to engage in relief action vis-à-vis what was constituted as the core of this cluster. Beyond opening up a space for active (re)engagement on the part of state authorities, the nationalization of shipping and shipping-related lines of business also created the possibility of a prospective maritime policy being granted a certain degree of legitimacy - this as a result of how the efforts would be made on behalf not of those directly involved in shipping and shipping-related lines of business, but of the nation as a whole.

Secondly, the nationalism integral to the efforts to develop a maritime policy had the effect of naturalizing shipping and shipping-related lines of business in Norway. This follows from how an engagement in such activities was constituted as natural for Norway and Norwegians in connection with the production of an ethno-cultural maritime identity. The sense of naturalness in question was effected in two ways, the first of which concerned the geographical make-up of Norway. In this connection, shipping and shipping-related activities were depicted as natural products of Norway being a 'coastal nation': 'With its long coast, Norway has always been a nation of seafarers' (Wergeland, 1992: 20). The second way in which a sense of naturalness related to an engagement in shipping and shipping-related activities was effected concerned the internal make-up of people in Norway. Rather than being imposed on Norwegians by conditions set by an external nature, such engagement was portrayed as driven by a nature internal to Norwegians: 'As summed up by the poet, "Norwegians have always wanted to seafare", (Reve et al., 1992: 34), and '[w] here ships can float, there [the Norwegian seaman] is the first man'. ${ }^{6}$

Irrespective of the source, the naturalization of an engagement in shipping that follows from its portrayal as a question merely of living in accordance with conditions set by nature and/or giving outlet to a maritime nature is a clear instance of depoliticization. Not only did it work to erase the politics associated with shipping of earlier times - whether related to fundamental quarrels of the kind that prevailed in connection with the parliamentary debate on a commercial treaty with France in 1865, or the innumerable favours that shipping has been granted since it emerged as a separate line of business in the second half of the nineteenth century - but it also worked to move shipping and shipping-related activities outside of politics in the present. Given the difficulties involved in arguing against 'nature', it ruled out any fundamental questioning of shipping and shippingrelated activities in Norway.

Thirdly, the nationalism integral to the efforts to develop a maritime policy had the effect of sacralizing shipping and shipping-related lines of business in Norway. This follows primarily from how such activities were depicted as 'traditions' in connection with the ascription of an ethnocultural maritime identity onto Norway and Norwegians. As mentioned earlier, the term 'tradition' implies the general idea of handing down or transmitting from one generation to the next, and its invocation thus works to establish a sense of continuity between the past and the present between those who supposedly live the tradition today and those who supposedly handed it down. While the word can have both positive and nega- 
tive connotations, it was used in an unequivocally positive sense in connection with the efforts to develop a maritime policy. In other words, the traditions related to shipping and shipping-related activities were depicted not only as having deep historical roots, but also as being of a particularly proud and honourable kind.

Used in this way, the term tradition entails strong normative implications as to how one should relate to that which is being traditionalized. At a minimum, it calls for respect vis-à-vis both the tradition and the generations that handed it down. Furthermore, it implies conservatism in the sense that it calls for the maintenance or preservation of that which is constituted as a tradition. In other words, one should not abandon a tradition, but rather seek to be true to and live in accordance with it. Moreover, a tradition is not only worthy of respect, reverence and awe, but also something that should be actively protected if necessary. Against this background, the depiction of shipping and shipping-related activities as traditions worked to constitute them not only as worthy of profound reverence, but also as more or less inviolable - that is, something that cannot or should not be transgressed, dishonoured or broken. Given how they were seen to have brought honour, glory and power to Norway and Norwegians, to do otherwise would be shameful at best, and sinful at worst.

Fourthly, the nationalism integral to the efforts to develop a maritime policy had the effect of existentializing shipping and shipping-related lines of business in Norway. This follows from how they were constituted as a symbol of what Norwegians are as a nation in and through the ascription of an essentialist maritime identity onto Norway and Norwegians. By being constituted as a symbol of 'what we are' and seemingly always have been, shipping and shipping-related activities were also constituted as something without which 'we' would no longer be 'us'. In consequence, a possible threat to such activities becomes a threat to 'our' sense of 'ourselves' as 'ourselves', while their preservation becomes a question of preserving Norway and Norwegians as 'what we are'. Furthermore, the business policy question of whether or not to make an effort in shipping becomes a question of cultivating or suppressing things Norwegian. A more fundamental questioning of shipping and shipping-related activities in Norway becomes almost equal to being against 'us', and this leaves few options but to actively cultivate shipping and other maritime businesses.

Fifthly, the nationalism integral to the efforts to develop a maritime policy had the effect of idealizing shipping and shipping-related lines of business in Norway. This follows from how such activities were constituted as an exemplar type of business activity in connection with the (re)production of Norway as a nation in economic terms. In this connection, the significant thing to note is that Porter's cluster theory came together with a developmental model, and that Norway was ascribed meaning as follows within it:

Seen from the outside, Norway is located both in the first phase characterised by factor-driven industry, and in the last phase with a high level of prosperity and many arrangements for income distribution. This is not the post- 
industrial society in which everybody is happily engaged in the production of services, but rather a society in industrial dissolution and with failing industrial competitiveness. (Reve et al., 1992: 17)

Although the overall picture painted of Norway as an economic nation was very gloomy, the Porter research brought some consolation by pointing to the potential that existed in a few industries - including, not least, in shipping and related lines of business. These were considered not only to be internationally competitive, but to be so on the basis of the key feature of the third phase of national competitive development - namely knowledge. 'We have no cost or nature-based advantages', claimed Reve et al., 'shipping is a pure competence industry' (ibid.: 199-200). While constituted as something atypical and almost 'non-Norwegian' in the context of the otherwise so dismal state of affairs in Norway, the maritime businesses nevertheless appeared as the kind of internationally competitive 'knowledge industries' that ought to prevail in Norway.

As the politicians more or less unanimously both shared the Porter researchers' enthusiasm for so-called knowledge industries, and joined in the cheering of shipping and shipping-related lines of business as being among the very few internationally competitive Norwegian lines of business that were not resource-based, the effect of the (re)production of Norway as an economic nation on the efforts to develop a maritime policy should be clear: Shipping and other maritime business activities could not but be cultivated as part and parcel of a more general transformation of Norway towards the ideal of an innovative and internationally competitive knowledge economy. Suggesting anything else would be stupid at best, and reactionary at worst.

\section{Maritime Policy and Nationalist Inclusion/Exclusion}

In this section, the focus is the exclusionary effects of Norway being ascribed a maritime identity in connection with the efforts to develop a maritime policy. With national identity considered a product of a two-fold process in and through which identity/difference is conceived in internationalist terms, and with a nation ascribed characteristics that constitute it as different from other nations, national identity constructions cannot but be exclusionary with respect to both that which is constituted as external to a nation (externalized differences), and that which is somehow internal to a nation, but nevertheless do not share the characteristics ascribed to the action (internalized differences). In the current context, this implies a concern with inclusion/exclusion connected with how the maritime identity construction worked both to mark off Norway as one among several nations, and to mark Norway and Norwegians as a nation.

With regard to the former issue, it was argued above that the maritime identity was primarily produced in and through the constitution of maritime business activity as a marker of difference within the inter-nationalist system of representation. Moreover, the nationalization of a part of world 
maritime business activity that followed an inter-nationalization of the latter worked to constitute Norway as a nation primarily in legal-political terms. Against this background, the maritime identity construction can initially be claimed to work to exclude bodies and things not linked to Norway through citizenship. If inclusion/exclusion based on citizenship is considered in relation to maritime business activity, then the identity construction works to exclude the vast majority of sailors working on board 'Norwegian' foreign-going vessels. ${ }^{7}$ Regardless of these 'non-Norwegian' sailors spending more days annually on territories subject to Norwegian jurisdiction than many shipowners with Norwegian citizenship, and of the 'Norwegian' fleet afloat on the world oceans on the basis of their labour, they are largely excluded from Norway as a legal-political nation.

With respect to how the maritime identity construction worked to mark Norway and Norwegians as a nation, the question of inclusion/exclusion should be considered on the basis of the national-symbolic meanings that were ascribed to shipping and the maritime lines of business in connection with the efforts to develop a maritime policy. In more specific terms, it should be considered against the background of how these lines of business were constituted as symbols or embodiments of what Norway and Norwegians both 'are' in ethno-cultural terms, and 'ought to be' in economic-territorial terms. The first issue was discussed in connection with the existentialization of shipping and shipping-related lines of business, and inclusion/exclusion becomes here a question of sharing or not the elements integral to the maritimization of Norway and Norwegians. In this connection, the maritime identity construction can be claimed to be exclusionary with regard to geography, gender and ethnicity/race.

Firstly, the maritime identity construction is exclusionary with regard to citizens of Norway that live neither by the sea, nor on the sea. In this connection, and contrary to the impression created through the portrayal of Norway as 'a narrow island with short distance to the coast throughout the country', it should be stressed that a large number of people simply do not live 'by the sea'. Furthermore, and with reference to the centrality of shipping in the maritime identity construction, it has to be stressed that a large number of people living by the coast simply do not live 'on the sea'. Moreover, and among people that can be claimed somehow to live on the sea, a large number simply do not engage in the kind of activities that the efforts to develop a maritime policy were concerned with. In consequence, the claim that 'people have always lived by the sea, off the sea and on the sea' makes little sense unless one's concern is with a steadily diminishing minority of people.

Expressed differently, the maritime identity construction can at best be considered a de-particularized version of a coastal identity construction. Being no less constructed than a national identity, a 'coastal Norway' has tended to be produced in and through a differentiation from a coconstructed 'agrarian Norway' or 'inland Norway': 'When we think about coastal culture, it is commonly in contrast to that culture which does not exist along the coast - the coast is different from the inland' (Klepp, 1992a: 9). Although there is a tendency to use the notion 'coastal culture' 
in the singular, scholars on things coastal have concluded that it is 'never a question of one coastal culture' (Klepp, 1992b: 11). In more specific terms, Fjellheim (1992: 17) has stressed that 'coastal culture' is much more than both seafaring and fishing, while Klepp (1992a: 13) has emphasized that coastal culture has always been not only maritime culture, but also peasant culture.

With regard to shipping and shipping-related activities, it is clear that these are much less evenly distributed along the coast of Norway than the picture painted in connection with the efforts to develop a maritime policy. Firstly, such activities are heavily concentrated in the southern parts of Norway. Secondly, there is a strong concentration of such activities in a few cities. As noted by Reve et al.: 'Previously, most towns along the coast from Oslo to Bergen were seafaring towns. (...) Today, the demands for largescale operation have resulted in a concentration around Oslo and Bergen' (1992: 193). Against this background, the maritime identity construction that was de-particularized and nationalized in connection with the efforts to develop a maritime policy can be conceived not so much as a coastal identity construction as a sub-coastal one attached to a limited number of greater urban areas in southern Norway.

Secondly, the maritime identity construction is exclusionary with regard to citizens of Norway who are women. ${ }^{8}$ Although there certainly are women living 'by the sea', it is clear that life at sea has historically been preserved for men. The term sjømann (seaman) and derivatives such as sjømannsskap (seamanship) are telling in this connection, as are the names of institutions such as the Directorate for Seamen and the Seamen's Union. Brit Berggreen has introduced the term 'seawoman' with reference to 'women that have a vessel as dwelling and/or place of work for a more or less longlasting period' (1985: 12), but can be charged with making too much out of their limited participation in family-run coastal shipping or as ladies' companions (Trysnes, 1989). While women have 'played roles in the maritime life as seamen's mothers, sisters, girlfriends and wives' (Berggreen et al., 1989: 7) — and, one could add, as prostitutes - they have been secondary actors in a man's maritime world, and been ascribed meaning on the basis of their position vis-à-vis the male character and his needs.

Being a male environment, there has been a tendency to ascribe 'life at sea' value on the basis of its contribution to the cultivation of 'some of the best masculine characteristics: fearlessness, endurance, intrepidity and resourcefulness' (Keilhau, 1948:111-12). In what was the standard primary school reader from the mid-1890s to the 1950s (Rolfsen, 1892-95), the editor included as much as he did on 'life at sea' to ensure that 'the children should not be without knowledge about that class which through its daily work keeps the people's sense of manly achievement alive' (Rolfsen, 1896). Moreover, a 'voyage at sea' has functioned as an important rite of passage through which boys became 'real men' (Disen, 1996). Against this background, it is no surprise to find that an identification of things Norwegian with things maritime has often resulted in an identification of the former with conditions specific for men or norms ascribed to what it means to be a man. 
Not only was it acknowledged in the white paper that '[s]eafaring is traditionally strongly male dominated' (St.meld., 1995-96: 22), but there was also a wish on the part of politicians to include women. ${ }^{9}$ This was evident in both the use of specifications like 'men and women' and 'boys and girls', and a clearly articulated wish to break with the male domination:

It is important for the whole maritime milieu that youth of both sexes are recruited to maritime education. Special emphasis should be placed on motivating, recruiting and preparing for women to take education and choose a career within the maritime businesses. (St.meld., 1995-96: 7)

Irrespective of this, and if it is also taken into account both that 'the Norwegian seaman identity' continues to be constituted as a typical masculine identity (Serck-Hansen, 1996), and that the Ministry of Foreign Affairs until recently promoted Norway with reference to how the relationship to the sea has 'created our fame (image) as tough heroes and daredevils' (quoted in Johansen, 1995: 23), then the identification of things Norwegian with things maritime works to exclude women.

Thirdly, the maritime identity production is exclusionary also in ethnocultural or racial terms with regard to citizens of Norway that became so only more recently and/or whose physical appearance or cultural practices deviate from the 'norm'. The concern here is not so much with the maritime content of the identity construction in question, but rather with the underlying (re)production of Norway as a collective identity group in ethno-cultural terms. In this connection, and against the background of how being 'Norwegian' is made dependent on sharing culture, traditions, history and ancestry across many generations, it should be fairly obvious that the maritime identity construction has little to offer in the form of inclusion to recent migrants to Norway. In contrast, it has much to offer descendants of people who previously migrated from Norway — such as the approximately 4.5 million 'Norwegian-Americans' in the USA. ${ }^{10}$

Beyond this, the (re)production of Norway as a nation in ethno-cultural terms that underpinned the maritime identity construction is exclusionary also on the basis of how it feeds on and into more popular conceptions of what it means to be 'Norwegian'. In this connection, there is no doubt that most such conceptions include ethno-cultural or racial criteria that go far beyond the obtainment of formal citizenship. Although most citizens of Norway can be claimed to be migrants to Norway, only some people remain 'immigrants' or 'foreigners' in common language use, and they do so due not to the recency of their migration, but to how their physical appearance or cultural practices deviate from 'what is expected'. Moreover, there is a clear tendency to preserve the notion nordmenn (Norwegian) for people who appear to be of the genuine stock, and to use compounds like norsk-pakistaner (Norwegian-Pakistani) for others - constituting 'Norwegian' as a secondary characteristic of what is first and foremost constituted as 'non-Norwegian'.

Irrespective of multiple anti-racism campaigns, declarations of a 'multicultural Norway', and public calls for an acceptance of citizens with 
'foreign-cultural' or 'distant-cultural' backgrounds - notions that themselves place the people in question at a clear distance - conceptions of what it means to be 'Norwegian' that are based on a (re)production of Norway as a nation in ethno-cultural terms tend to postpone indefinitely the prospect of inclusion for citizens of Norway who cannot easily disappear in the 'Norwegian' crowd. Given how the maritime identity construction is linked to a myth of 'national' descent and origin, it cannot but be complicit in the exclusions discussed above. Just like 'there ain't no black in the Union Jack' (Gilroy, 1987), there ain't no space for a coloured Viking in Norway.

With regard to the issue of how shipping and shipping-related lines of business were constituted as symbols or embodiments of what Norway and Norwegians 'ought to be' in economic-territorial terms, inclusion/exclusion follows from how these lines of business were idealized and 'normified' within Porter's theoretical framework. In and through the constitution of 'type of business' as a marker of difference, shipping and shipping-related lines of business were ascribed meaning as the kind of future-oriented business activity that was claimed to characterize 'advanced' nations, and which ought to prevail in Norway. In consequence, inclusion/exclusion becomes here a question of having or not the key characteristics or qualities integral to the idealization of the maritime lines of business in general, and shipping in particular. Against this background, the maritime identity construction can be claimed to be exclusionary with regard to a line of business's geographical orientation, degree of competitiveness, and source of competitiveness.

Firstly, the maritime identity construction is exclusionary with regard to lines of business that do not have an 'international' orientation. Throughout the efforts to develop a maritime policy, shipping was hailed as 'Norway's most international line of business', while the maritime lines of business in general were positively recognized as 'lines of business with a strong international orientation' (St.meld., 1995-96: 5, 11). This ascription of an unequivocal positive value to internationally oriented business activity followed from the single-minded preoccupation with internationally engaged firms and industries in Porter's theory and the Norwegian Porter project. The latter conducted a strategic analysis of Norway as an export nation, and drew conclusions as to how Norway at large should be transformed to serve the needs of the industries analysed. In a Norway geared towards the international, there is simply no positive space left for firms and industries without such an orientation.

Secondly, the maritime identity construction is exclusionary with regard to lines of business that either do not occupy a competitive position, or for some reason are deemed uncompetitive. The positive references given to shipping and shipping-related lines of business as 'internationally competitive' were plenty, and this followed from how 'competitiveness' was constituted as the most central quality within Porter's theory. 'Competition' is the name of the only game in Porter town, and if a particular firm or industry cannot succeed in it, then its prospects for survival are bleaker than bleak - this, because the logic at work is not merely the 'natural selection' and 
'survival of the fittest' of social darwinism (Thurow, 1990), but a 'double survival of the fittest' according to which firms and industries constituted as fit according to 'Porter selection' should be actively stimulated and made fitter than fit. In consequence, there is little space left for those that cannot live up to the constitution of 'Norwegian' as 'a trademark signalling quality and competitiveness' (St.meld., 1995-96: 3).

Thirdly, the maritime identity construction is exclusionary with regard to lines of business whose source of competitiveness is not knowledge. The positive value ascribed to shipping and shipping-related lines of business as 'knowledge industries' followed from how such industries were constituted as 'the backbone of advanced economies' (Porter, 1990: 73). While Porter's developmental model of national competitiveness implied a clear hierarchical ordering of the basis for internationally competitive business activities - with 'nature' subordinated to 'capital', and the latter subordinated to 'knowledge' - the idealization of shipping and shipping-related lines of business was primarily based on a dichotomy between knowledge and nature, and stress was placed on the need to stimulate lines of business that fit with the knowledge-driven and capital-driven phases of national competitive development. In other words, the maritime identity construction worked to devalue industries competing internationally on the basis of socalled basic factors of production.

\section{Concluding Remarks}

While conventional usages of 'economic nationalism' with reference to the state and/or illiberal economic policies are likely to persist, a formidable challenge has been posed by recent efforts to redefine it by placing nationalism and national identity at its core. In his contribution to these efforts, Helleiner specified a new research agenda on economic nationalism in terms of a core problematic identified by List: 'In what ways do national identities and nationalism influence economic policy and processes?' With this as a point of departure, I have done three things in this article: Firstly, I have argued that the agenda in question should concern not merely how national identities and nationalism influence economic policies and processes, but also how economic policies and processes can influence national identities and nationalism. Secondly, I have argued in favour of the two-way relationship in question being conceived in constitutive rather than causal terms. Thirdly, I have presented an analysis of the co-constitutive relationship between nation and economy in connection with the efforts to develop a maritime policy in Norway in the mid-1990s.

The analysis as such has brought out how Norway was (re)produced as a nation in and through its explicit conceptualization as such, usages of the deixis of homeland, an inter-nationalization of economic competition, a nationalization of a part of world maritime activity, and the ascription of a set of non-economic meanings to shipping and things maritime; how Norway and Norwegians were (re)ascribed a sea-related identity in and through both the constitution of maritime business activity as an inter- 
national marker of difference, and a maritimization of Norway and Norwegians; how the nationalism integral to the maritime policy efforts contributed to shape how it was possible for policy-makers to think and act in relation to maritime lines of business - this, as a result of how it worked to nationalize, naturalize, de-politicize, sacralize, existentialize and idealize these lines of business; and how the maritime identity construction was exclusionary with regard not only to citizenship, but also to geography, gender, ethnicity/race and type of business activity.

Beyond this, the empirical case also provides support to two key propositions made in the more recent literature on economic nationalism: Firstly, it supports the proposition that there is no inherent contradiction between economic nationalism, on the one hand, and liberal economic policies, on the other. Although the maritime policy did imply subsidization of shipping activity located in Norway, the underlying cluster theory is liberal at heart, and state authorities in Norway are committed to a liberal world economic order in general and a liberal world shipping order in particular. Secondly, the study supports the proposition that there is no inherent contradiction between economic nationalism, on the one hand, and economic globalization, on the other. Not only were the efforts to develop a maritime policy informed by both a globalist conception of the world economy and a perceived need to foster industries that can succeed in global competition, but the seemingly ultra-Norwegian industry of shipping was conceived as a truly 'global industry'. Overall, then, nationalism went hand-in-hand with both liberalism and globalism in connection with the efforts to develop a maritime policy. ${ }^{11}$

\section{Notes}

I thank the referees and editors for comments on an earlier version of this article.

1. Helleiner makes particular reference to Abdelal (2001), Crane (1998, 1999) and Shulman (2000). More recent contributions include Bond et al. (2003) and Pickel (2003).

2. For a collection of studies attending to this task, see Helleiner and Pickel (2005).

3. On this quest for causality, see also Helleiner (2005: 232-4).

4. On the difference between constitution and causation in social research, see Wendt (1998).

5. Translated from Rolfsen and Mørkhagen (1993: 242-3).

6. The poet in question is again Bjørnson, and the quote is a brief, re-written version of the opening sentence in the song Norrønafolket (the Norse people) as included in his historical play Sigurd Jorsalfar (1872). The re-writing concerns the exchange of 'Norwegians' for 'the Norse people'.

7. As of 31 December 1994, more than $80 \%$ of the sailors employed in the NISregistered fleet were not citizens of Norway (St.meld., 1995-96: 23).

8. Note that there is a tendency to equalize also a coastal culture with 'male culture' (Jensen, 1992). 
9. As of December 1994, women made up $8.6 \%$ of the sailors with Norwegian citizenship, and 8.1\% of such sailors in foreign-going shipping (MIRG, 1995: 51).

10. US Census 2000 (http://factfinder.census.gov). Accessed 22 October 2005.

11. For a further discussion on these issues, see Fougner (2002).

\section{References}

Abdelal, R. (2001) National Purpose in the World Economy: Post-Soviet States in a Comparative Perspective. Ithaca, NY: Cornell University Press.

Berggreen, B. (1985) 'Sjøkvinner: Om å Oppdage et Forskningsfelt', Skärgård 18: 4-12.

Berggreen, B., Christensen, A. E. and Kolltveit, B. (1989) 'Forord', in B. Berggreen, A. E. Christensen and B. Kolltveit (eds) Norsk Sjøfart, Vol. 1, pp. 7-8. Oslo: Dreyer.

Bergh,T. and Hanisch, T. (1984) Vitenskap og Politikk: Linjer i Norsk Sosialøkonomi gjennom 150 år. Oslo: Aschehoug.

Billig, M. (1995) Banal Nationalism. London: Sage.

Bjørnson, B. (1872) Sigurd Jorsalfar. Copenhagen: Gyldendal.

Bond, R., McCrone, D. and Brown, A. (2003) 'National Identity and Economic Development: Reiteration, Recapture, Reinterpretation and Reputation', Nations and Nationalism 9: 371-91.

Bugge, A. (1904-06) Vikingerne: Billeder fra Vore Forfadres Liv, 2 vols. Kristiania: Nordisk Forlag.

Calhoun, C. (1995) Critical Social Theory: Culture, History, and the Challenge of Difference. Oxford: Blackwell.

Calhoun, C. (1997) Nationalism. Buckingham: Open University Press.

Connolly, W. E. (1991) Identity/Difference: Democratic Negotiations of Political Paradox. Ithaca, NY: Cornell University Press.

Crane, G. T. (1998) 'Economic Nationalism: Bringing the Nation Back In', Millennium 27: 55-75.

Crane, G. T. (1999) 'Imagining the Economic Nation: Globalisation in China', New Political Economy 4: 215-32.

Disen, K. L. (1996) 'Om Hvordan det Ble Mannfolk av Gutter - Sosialisering i Førindustrielle Kystsamfunn', Materialisten 24: 63-86.

Fjellheim, B. (1992) 'Kystkultur og Kystnæring i Endring', in A. Løseth and P. Sæther (eds) Kystkultur: Sarpreg and Mangfald, pp. 17-27. Volda: Sunnmøre Museum and Møre og Romsdal Distriktshøyskole.

Fougner, T. (2002) 'Politically at Sea: Problematising the New Norwegian Shipping Policy of 1996.' PhD dissertation, Keele University.

Gilroy, P. (1987) 'There Ain't No Black in the Union Jack': The Cultural Politics of Race and Nation. London: Unwin Hyman.

Haavardsholm, J. (1999) 'Vikinger til Glede og Besvær', in B. Rogan (ed.) Norge Anno 1900: Kulturhistoriske Glimt fra et Arhundreskifte, pp. 307-22. Oslo: Pax forlag.

Hall, S. (1990) 'Cultural Identity and Diaspora', in J. Rutherford (ed.) Identity: Community, Culture, Difference, pp. 222-37. London: Lawrence \& Wishart.

Handler, R. (1994) 'Is "Identity" a Useful Cross-Cultural Concept?', in J. R. Gillis (ed.) Commemoration: The Politics of National Identity, pp. 27-40. Princeton, NJ: Princeton University Press.

Helleiner, E. (2002) 'Economic Nationalism as a Challenge to Economic 
Liberalism? Lessons from the 19th Century', International Studies Quarterly 46: 307-29.

Helleiner, E. (2005) 'Conclusion: The Meaning and Contemporary Significance of Economic Nationalism', in E. Helleiner and A. Pickel (eds) Economic Nationalism in a Globalizing World, pp. 220-34. Ithaca, NY: Cornell University Press.

Helleiner, E. and Pickel, A. (eds) (2005) Economic Nationalism in a Globalizing World, pp. 220-34. Ithaca, NY: Cornell University Press.

Innst. O. (1995-96) 'Instilling fra Finanskomiteen om Endringer i Skipsfartsbeskatningen', Instilling til Odelstinget 81. Oslo: Standing Committee on Finance and Economic Affairs.

Innst. S. (1995-96) 'Instilling fra Næringskomiteen om Hvor Fartøy Flyte Kan ... De Maritime Næringer', Instilling til Stortinget 241. Oslo: Standing Committee on Business and Industry.

Jensen, I. (1992) 'Kvinner i Kyst-Norge', in A. Løseth and P. Sæther (eds) Kystkultur: Sarpreg og Mangfald, pp. 28-39. Volda: Sunnmøre Museum and Møre og Romsdal Distriktshøyskole.

Johansen, A. (1995) Den Store Misforståelsen: 'Kulturarv' og 'Nasjonal Egenart' $i$ Norgesreklame og Politisk Kultur. En Advarsel. Oslo: Tiden.

Keilhau, W. (1948) Skipsfartens Betydning for Norge: En Utredning, 2nd rev ed. Oslo: Norges Rederforbund.

Kiær, A. N. (1900) 'Norges Søfart', in N. Rolfsen and E. Werenskiold (eds) Norge i det Nittende Aarhundrede, vol. 2, pp. 297-305. Kristiania: Alb. Cammermeyers Forlag.

Klepp, A. (ed.) (1992a) Kystkultur. Oslo: Institute for Ethnology, University of Oslo.

Klepp, A. (1992b) 'Hva er kystkultur?', in A. Løseth and P. Sæther (eds) Kystkultur: Scerpreg og Mangfald, pp. 7-16. Volda: Sunnmøre Museum and Møre og Romsdal Distriktshøyskole.

MIRG (1995) 'Rapport fra Handelsministerens Idé- og Ressursgruppe til Maritim Stortingsmelding', September.

Nereid, C. T. (1996) “"Fram-Gutterne”, Sønner av Norge som ikke var Brødre, eller Historien om den Glemte Polfarer Anton Amundsen', in A. Thowsen and T. L. Nielsen (eds) Sjøfartshistorisk Arbok 1995, pp. 31-48. Bergen: Foreningen 'Bergens Sjøfartsmuseum'.

O.tid. (1995-96) 'Innstilling fra Finanskomiteen om Endringer i Skipsfartsbeskatningen', Odelstingstidende, pp. 560-86.

Ot.prp. (1995-96) 'Endringer i Skipsfartsbeskatningen', Odeltingsproposisjon 36. Oslo: Ministry of Finance.

Pickel, A. (2003) 'Explaining, and Explaining with, Economic Nationalism', Nations and Nationalism 9: 105-27.

Porter, M. E. (1990) The Competitive Advantage of Nations. London: Macmillan.

Rée, J. (1998) 'Cosmopolitanism and the Experience of Nationality', in P. Cheah and B. Robbins (eds) Cosmopolitics: Thinking and Feeling Beyond the Nation, pp. 77-90. Minneapolis: University of Minnesota Press.

Reve, T., Lensberg, T. and Grønhaug, K. (1992) Et Konkurransedyktig Norge. Oslo: Tano.

Rolfsen, J. N. B. (1892-95) Laesebok for Folkeskolen, 5 vols. Kristiania: Jacob Dybwads Forlag.

Rolfsen, J. N. B. (1896) Sjømand: Norske Sjømands Oplevelser: Samlet fra Folkemunde og Gjenfortalt. Kristiania: De Tusen Hjems Forlag.

Rolfsen, C. N. and Mørkhagen, S. (eds) (1993) Århundrets Lesebok: Tekster fra Nordahl Rolfsens Lesebøker. Oslo: Grøndahl Dreyer. 
Serck-Hansen, C. (1996) “ "De er ikke Ordentlige Sjøfolk, De er her bare for å Tjene Penger"', Hovedfagstudentenes Arbok, vol. 9, pp. 171-7. Oslo: Institute and Museum for Anthropology.

Shulman, S. (2000) 'Nationalist Sources of International Economic Integration', International Studies Quarterly 44: 365-90.

Sørensen, Ø. (ed.) (1998) Jakten på det Norske: Perspektiver på Utviklingen av en Norsk Nasjonal Identitet på 1800-tallet. Oslo: Ad notam Gyldendal.

S.tid. (1865-66) 'Ang. Traktaten med Frankrig', Stortingstidende, pp. 25-75.

S.tid. (1993-94) 'Innstilling fra Næringskomiteen om Sjøfartsdirektoratets Virksomhet i 1992 og 1993', Stortingstidende, pp. 3927-32.

S.tid. (1995-96) 'Innstilling fra Næringskomiteen om Hvor Fartøy Flyte kan ... De Maritime Næringer', Stortingstidende, pp. 4208-38.

St.meld. (1995-96) 'Hvor Fartøy Flyte kan ...: De Maritime Næringer', Stortingsmelding 28. Oslo: Ministry of Foreign Affairs.

Sturlason, S. (1899) Kongesagaer. Kristiania: J. M. Stenersen.

Thurow, L. C. (1990) 'Competing Nations: Survival of the Fittest', Sloan Management Review 32: 95-7.

Trysnes, F. S. (1989) 'Kvinner og Skipsfart: Var Kvinner med til Sjøs? Hvordan Innrettet Kvinnene seg Hjemme når Mannen var Borte?', in B. E. Johnsen (ed.) Sjøfolks Hverdag, pp. 86-109. Kristiansand: Agder Distriktshøyskole.

Wendt, A. (1998) 'On Constitution and Causation in International Relations', Review of International Studies 24: 101-17.

Wergeland, T. (1992) 'Et Konkurransedyktig Norge: Norsk Skipsfarts Konkurranseevne', SNF-Report 50.

Worm-Müller, J. S. (1939) 'Bjørnstjerne Bjørnson og Havet', in J. S. Worm-Müller (1946) Til Norge: Taler og Artikler gjennom Krigsårene 1939-1945, pp. 19-29. Oslo: H. Aschehoug \& Co.

TORE FOUGNER is Assistant Professor in the Department of International Relations at Bilkent University, Ankara, Turkey.

Address: Department of Internatinal Relations, Bilkent University, 06800 Ankara, Turkey.

[email: fougner@bilkent.edu.tr] 